\title{
EVALUATION OF DISINFECTANT PRODUCTS FOR MICROBIAL DECONTAMINATION OF IMPORTED USED FOOTWEAR
}

\author{
L-H. CHEAH ${ }^{1}$, A.T. MARSH ${ }^{1}$, M.R. MCNEILL ${ }^{2}$ and D.I. HEDDERLEY ${ }^{1}$ \\ ${ }^{1}$ The New Zealand Institute for Plant \& Food Research Limited, Private Bag \\ 11600, Palmerston North 4442, New Zealand \\ ${ }^{2}$ AgResearch, Lincoln, Private Bag 4749, Christchurch 8140, New Zealand
}

Corresponding author: cheahl@crop.cri.nz

\begin{abstract}
Fourteen disinfectants were tested in vitro for activity against soil bacteria and fungi attached to a boot worn in New Zealand, and then eight were further evaluated on three types of field-worn footwear. From in vitro tests

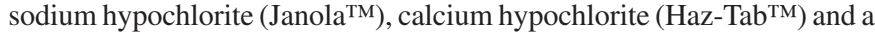
quaternary ammonium product (Trimove ${ }^{\circledR}$ ) gave almost complete kill of bacteria. Four disinfectants (sodium hypochlorite, phenols (Prephen ${ }^{\mathrm{TM}}$ ), hypochlorous acid plus hypobromous acid (Nylate ${ }^{\mathrm{TM}}$ ) and calcium hypochlorite) also gave complete kill of fungi. Field tests showed that five disinfectants (sodium hypochlorite, calcium hypochlorite, formaldehyde, hypochlorous acid plus hypobromous acid, and the quaternary ammonium product) were as effective as dipotassium peroxodisulphate (Virkon ${ }^{\circledR}$ - a standard biosecurity treatment for disinfecting footwear). Sodium hypochlorite was found to be significantly more effective than dipotassium peroxodisulphate for disinfecting shoes of soil fungi. The disinfectants caused no visible changes in colour or damage to footwear materials. Keywords: biosecurity, disinfectant, bacteria, fungi.
\end{abstract}

\section{INTRODUCTION}

Soiled footwear worn by overseas visitors or carried in their luggage could inadvertently introduce a range of unwanted organisms into New Zealand. Among these are bacteria and fungi that could threaten our indigenous flora or economically important crops. Current airport biosecurity protocols require inspection of footwear that is contaminated with soil or has been used in outdoor sport or recreation, particularly if the passenger has visited a farm or forest. If the contamination is significant, the items of footwear are physically cleaned of any contaminant, followed by dipping in the disinfectant dipotassium peroxodisulphate $\left(\right.$ Virkon $\left.^{\circledR}\right)$. The footwear is then bagged and returned to the passenger.

In a study examining the effectiveness of Virkon ${ }^{\circledR}$ in reducing numbers of aerobic bacteria on minimally contaminated footwear, it was found that brushing and dipping of soles in the disinfectant, similar to the procedure used at New Zealand international airports, did not give adequate control of aerobic bacteria (Amass et al. 2005). Only when the soles of footwear were dried after treatment with Virkon ${ }^{\circledR}$ was there a significant reduction in bacterial numbers (Amass et al 2005). In a preliminary study comparing the disinfectants Virkon ${ }^{\circledR}$ and TriGene Advance ${ }^{\mathrm{TM}}$ with a surfactant (Polysorbate 80 ) and water only, Young et al. (2008) found that, after first removing the majority of soil with a brush, all treatments significantly reduced bacterial and fungal loading. However, there was no significant difference between the treatments.

In the light of these results, the present study was instigated to look at what alternative chemicals could also be used in place of Virkon ${ }^{\circledR}$ should the product be unavailable. The commercially available disinfectants that were considered suitable for sterilising 
footwear had not been evaluated for their efficacy against soil microorganisms. The aim of this project was to simulate the procedures used by MAF Biosecurity NZ against bacteria and fungi present in soil that had been obtained from footwear worn in New Zealand. It also provided an opportunity to test whether these disinfectants could cause any damage to footwear materials.

\section{MATERIALS AND METHODS}

\section{In vitro tests}

Fourteen commercially available disinfectants prepared as per the manufacturers' recommendations were tested in two separate experiments (in 2007, Table 1 and in 2008, Table 2). Soil was scraped from the sole of a boot worn in field soil in New Zealand for about 1 month, and $1 \mathrm{~g}$ of this soil was added to $10 \mathrm{ml}$ of sterile water, which was then mixed well with a vortex mixer. An aliquot $(1 \mathrm{ml})$ of the soil solution was added to each of $10 \mathrm{ml}$ of disinfectant solutions, mixed well and left to stand for $5 \mathrm{~min}$. Aliquots of $100 \mu \mathrm{l}$ of each disinfectant dilution were spread onto agar plates using a sterile glass rod. For each treatment, two plates of PDA with cefotaxime antibiotic (100 ppm, for isolating fungi) and two plates of nutrient agar (Difco ${ }^{\mathrm{TM}}$ Laboratories, USA, for bacteria) were used. Each treatment was repeated four times. Numbers of bacterial and fungal colonies (colony forming units - CFU) on the plates were recorded 3 and 5 days respectively after incubation at $22^{\circ} \mathrm{C}$.

\section{Field tests}

The aim of this test was to simulate practices that are carried out at the airports by the MAFBNZ border biosecurity staff to disinfect footwear worn by overseas visitors. Three types of footwear (walking shoes, rugby boots and gumboots) were field-tested by walking a designated route $(\sim 100 \mathrm{~m})$ through damp grasses and soil. Prior to each field test, the footwear was cleaned by washing thoroughly under running water then allowed to air dry. All field tests were carried out after a period of rain or heavy dew to allow for better adhesion of soil and debris to the footwear. Soil adhering to soles was allowed to dry at room temperature.

Loose soil and debris were brushed off each shoe. On one shoe from each pair, a $5 \mathrm{~cm}^{2}$ area on the sole (toe area or heel area decided by coin toss) was sampled by rubbing with a sterile swab moistened in D/E neutralising broth (Difco ${ }^{\text {TM }}$ Laboratories, USA), a chemical used to inactivate the disinfectant prior to spreading on the plate. This shoe was then washed by scrubbing the sole under running water. Another swab sample was then taken from the opposite end to the first sample (heel or toe area). These samples (water treated) were used as a comparison to the disinfectant treatments.

The second shoe of each pair was cleaned and sampled using the same prewash method, then treated with disinfectant by dipping the soles of the shoes in a solution of disinfectant (Table 3 ) for about $10 \mathrm{~s}$. Each shoe was then scrubbed under running water to remove all visible dirt before a final dip in the same solution was made. The treated shoes were left on a bench for about 1 min before a post-treatment swab sample was taken from the opposite end to the pre-treatment sample. All disinfectants were prepared as per the manufacturers' recommendations.

Each swab (four for each shoe type) was mixed well in $700 \mu \mathrm{l}$ D/E neutralising broth with a vortex mixer, and $100 \mu$ of each dilution spread onto an agar plate using a sterile glass rod. Solutions from each swab were cultured on two plates each of PDA with cefotaxime antibiotic and nutrient agar, as described above. CFUs of bacteria and fungi on the plates were recorded 3 and 5 days respectively after incubation at $22^{\circ} \mathrm{C}$. The experiment was repeated three times for each disinfectant and each shoe type.

\section{Shoe tests}

More than 100 individual second-hand footwear items made from different materials (leather, synthetic cloth, rubber, suede and plastic) and colours were used for the tests. No attempt was made to clean or remove the polishes on these shoes. About $5 \mathrm{ml}$ of each of the disinfectants (Tables 1 and 2) diluted to manufacturers' specifications was brushed onto the front of the sole and upper of each different shoe type. Treated footwear items 
were left to dry at room temperature. Control shoes were left untreated. Observations were made daily for 7 days to ascertain any change of colour or apparent damage to the different shoe materials.

Statistical analyses

Data from each year, comprising fungal and bacterial CFU, were analysed separately. The generalised linear mixed model fitted for each analysis, using GenStat (VSN International, Hemel Hempstead, 2006), had a Poisson distribution, a log link, a fixed effect for treatment and random effects for replicate and replicate by treatment. Least significant differences on the log scale were converted into least significant ratios (LSR) on the arithmetic scale and these were used to determine significance of differences between products.

\section{In vitro tests}

\section{RESULTS}

All of the test disinfectants, except potassium hydroxide and chlorine dioxide, reduced the $\mathrm{CFU}$ of bacteria and fungi compared with untreated experimental controls in both experiments (Tables 1 and 2). Sodium hypochlorite, calcium hypochlorite and a quaternary ammonium product (Trimove) killed almost all the bacteria in the soil solutions. Five disinfectants (sodium hypochlorite, phenols, hypochlorous acid plus hypobromous acid, calcium hypochlorite and a quaternary ammonium product) almost completely killed the fungi in the solutions.

TABLE 1: Mean numbers of colony forming units (CFU) of bacteria and fungi on agar plates inoculated with footwear soil solutions after treatment with different commercial disinfectants ( 2007 experiment).

\begin{tabular}{|c|c|c|c|c|}
\hline \multicolumn{2}{|l|}{ Disinfectant } & \multirow{2}{*}{$\begin{array}{l}\text { Rate (mg } \\
\text { a.i./litre) }\end{array}$} & \multirow{2}{*}{$\begin{array}{c}\text { Bacteria } \\
\text { (CFU/g } \\
\text { soil) }\end{array}$} & \multirow{2}{*}{$\begin{array}{c}\text { Fungi } \\
\text { (CFU/g } \\
\text { soil) }\end{array}$} \\
\hline Common name & Trade name & & & \\
\hline Untreated & Control & - & 6300 & 61.10 \\
\hline Chlorine dioxide & Expel $^{\mathrm{TM}}$ & 200 & 3160 & 53.30 \\
\hline Formaldehyde & Formalin ${ }^{\mathrm{TM}}$ & 37000 & 160 & 0.10 \\
\hline Calcium hypochlorite & $\mathrm{Haz}_{-} \mathrm{Tab}^{\mathrm{TM}}$ & 2500 & 70 & 0.00 \\
\hline Hypochlorous + hypobromous acid & Nylate $^{\mathrm{TM}}$ & 400 & 255 & 0.00 \\
\hline Phenols + ethanol & Prephen ${ }^{\mathrm{TM}}$ & 4000 & 100 & 0.00 \\
\hline Sodium hypochlorite & Janola $^{\mathrm{TM}}$ & 20000 & 5 & 0.00 \\
\hline Quaternary ammonium & Sterbac $^{\mathrm{TM}}$ & 1000 & 210 & 2.60 \\
\hline Ammonia + formaldehyde & Tri-film ${ }^{\mathrm{TM}}$ & 50000 & 275 & 0.40 \\
\hline Peroxyacetic acid & Tsunami ${ }^{\mathrm{TM}}$ & 1000 & 1060 & 6.90 \\
\hline Dipotassium peroxodisulphate & Virkon $^{\circledR}$ & 20000 & 425 & 5.20 \\
\hline Peroxyacetic + peroxyoctanoic acid & Vortex ${ }^{\mathrm{TM}}$ & 1000 & 865 & 1.80 \\
\hline Average $\mathrm{LSR}^{1}$ & & & $188 \%$ & $732 \%$ \\
\hline
\end{tabular}

${ }^{1}$ LSR: two means are significantly different if the larger is more than the product of the LSR being multiplied by the smaller. 
TABLE 2: Mean numbers of colony forming units (CFU) of bacteria and fungi on agar plates inoculated with footwear soil solutions after treatment with different commercial disinfectants (2008 experiment).

\begin{tabular}{|c|c|c|c|c|}
\hline \multicolumn{2}{|l|}{ Disinfectant } & \multirow{2}{*}{$\begin{array}{c}\text { Rate } \\
\text { (mg a.i./litre) }\end{array}$} & \multirow{2}{*}{$\begin{array}{c}\text { Bacteria } \\
(\mathrm{CFU} / \mathrm{g} \text { soil) }\end{array}$} & \multirow{2}{*}{$\begin{array}{c}\text { Fungi } \\
\text { (CFU/g } \\
\text { soil) }\end{array}$} \\
\hline Common name & Trade name & & & \\
\hline Untreated & Control & - & 7175 & 384.70 \\
\hline Sodium hypochlorite $\mathrm{pH} 7$ & Janola $^{\mathrm{TM}}$ & 20000 & 0 & 0.10 \\
\hline Sodium hypochlorite $\mathrm{pH} 12$ & Janola $^{\mathrm{TM}}$ & 20000 & 0 & 0.10 \\
\hline Calcium hypochlorite & $\mathrm{Haz}^{-T a b}{ }^{\mathrm{TM}}$ & 2500 & 20 & 0.30 \\
\hline Potassium hydroxide & $\operatorname{Decon}^{\circledR}$ & 25000 & 1935 & 73.40 \\
\hline Quaternary ammonium & Trimove $^{\circledR}$ & 25000 & 40 & 0.10 \\
\hline Quaternary ammonium & Florosan $^{\circledR}$ & 25000 & 220 & 0.20 \\
\hline Dipotassium peroxodisulphate & Virkon $^{\circledR}$ & 20000 & 115 & 1.00 \\
\hline Average $\mathrm{LSR}^{1}$ & & & $729 \%$ & $2595 \%$ \\
\hline
\end{tabular}

${ }^{1}$ LSR: two means are significantly different if the larger is more than the product of the LSR being multiplied by the smaller.

\section{Field tests}

Table 3 summarises the CFU of bacteria and fungi on the agar plates that resulted from field tests with different commercial disinfectants. Any form of washing significantly reduced bacterial CFUs $(\mathrm{P}<0.001)$; even washing with water alone removed $57 \%$ of bacteria. Overall, the disinfectant treatments reduced bacterial levels more than just water washing $(\mathrm{P}<0.001)$. Five disinfectants were found to be as effective as Virkon ${ }^{\circledR}$ in reducing bacteria from the shoes (Table 3). However, there was no significant difference between these treatments.

Any form of washing significantly reduced fungal CFUs $(\mathrm{P}<0.001)$; washing with water alone removed $80 \%$ of fungi. On average the disinfectant treatments reduced fungi levels significantly more than just water washing $(\mathrm{P}<0.001)$. Six of the disinfectants tested were found to be as effective as Virkon ${ }^{\circledR}$ in removing fungi from the shoes, with sodium hypochlorite significantly better (Table 3 ). Unlike with the bacteria, the differences between disinfectants was marginal $(\mathrm{P}=0.071)$.

\section{Shoe tests}

None of the disinfectants tested (Tables 1 and 2) caused any visible change of colour or damage to the footwear fabric on the different types of footwear materials.

\section{DISCUSSION}

New Zealand biosecurity authorities have identified soil on footwear as a potential hazard, so a proactive approach has been taken to intercepting and cleaning soil contaminated footwear. Few studies on the efficacy of disinfectants to sterilise soiled footwear using the procedures used at airports have been published. These studies have generally related to preventing the transmission of animal diseases in livestock rearing facilities (Amass et al. 2001), veterinary hospitals (Amass et al. 2006; Dunowska et al. 2006) or to environmentally sensitive ecosystems (Curry et al. 2005).

Recent research concerning footwear disinfection has shown that procedures need to be considered carefully if effective control of micro-organisms is to be achieved (Amass et al. 2005; Curry et al. 2005; Young et al. 2008). The present in vitro study showed that except for potassium hydroxide $\left(\right.$ Decon $\left.^{\circledR}\right)$ and chlorine dioxide (Expel $\left.{ }^{\mathrm{TM}}\right)$, all disinfectants tested reduced the growth of bacteria and fungi compared with untreated controls. At least five disinfectants, including sodium hypochlorite and Virkon ${ }^{\circledR}$, were highly effective in killing bacteria and fungi. Field test results showed sodium hypochlorite 
TABLE 3: Mean numbers of colony forming units of bacteria $\left(\mathrm{CFU} / \mathrm{cm}^{2}\right)$ and fungi (CFU/plate) on agar plates inoculated with dilutions made from footwear swabs applied after field use and treatment with different commercial disinfectants.

\begin{tabular}{|c|c|c|c|c|}
\hline \multicolumn{2}{|l|}{ Disinfectant } & \multirow{2}{*}{$\begin{array}{c}\text { Rate } \\
\text { (mg a.i.litre) }\end{array}$} & \multirow[b]{2}{*}{ Bacteria $^{1}$} & \multirow[b]{2}{*}{ Fungi ${ }^{1}$} \\
\hline Common name & Trade name & & & \\
\hline Unwashed - before treatment & & & $7.91^{+}$ & $23.11^{+}$ \\
\hline Water & Control & - & $3.37^{+}$ & 4.53 \\
\hline Calcium hypochlorite & Haz-Tab ${ }^{\mathrm{TM}}$ & 2500 & $0.64 *$ & 2.61 \\
\hline Formaldehyde & Formalin $^{\mathrm{TM}}$ & 37000 & $0.66 *$ & 2.61 \\
\hline Hypochlorous + hypobromous acid & Nylate $^{\mathrm{TM}}$ & 400 & $1.23 *$ & $0.79 *$ \\
\hline Phenols + ethanol & Prephen ${ }^{\mathrm{TM}}$ & 4000 & $1.64^{+}$ & $0.78 *$ \\
\hline Sodium hypochlorite & Janola & 20000 & $0.18 *$ & $0.24 * !$ \\
\hline Quaternary ammonium & Sterbac $^{\mathrm{TM}}$ & 1000 & $0.52 *$ & 1.22 \\
\hline Ammonia + formaldehyde & Tri-film ${ }^{\mathrm{TM}}$ & 50000 & $2.07^{+}$ & 3.78 \\
\hline $\begin{array}{l}\text { Dipotassium peroxodisulphate } \\
\text { LSRs }^{2}\end{array}$ & Virkon $^{\circledR}$ & 20000 & $0.39 *$ & 2.10 \\
\hline Control vs treatments & & & $223 \%$ & $256 \%$ \\
\hline Control vs sodium hypochlorite & & & $311 \%$ & $446 \%$ \\
\hline Among treatments & & & $314 \%$ & $368 \%$ \\
\hline Treatments vs sodium hypochlorite & & & $395 \%$ & $570 \%$ \\
\hline
\end{tabular}

${ }^{1}$ Symbols indicate treatment differences: *treatments significantly lower than the water and unwashed controls; !treatments significantly lower than Virkon ${ }^{\circledR}$; ${ }^{+}$treatments significantly higher than Virkon ${ }^{\circledR}$.

${ }^{2}$ LSR: two means are significantly different if the larger is more than the product of the LSR being multiplied by the smaller.

was as effective as Virkon ${ }^{\circledR}$ for killing soil bacteria and significantly more effective than Virkon ${ }^{\circledR}$ for killing soil fungi. The present results indicate that sodium hypochlorite could be an alternative to Virkon ${ }^{\circledR}$.

The present results also indicate that in general, washing footwear in water alone can remove significant numbers of bacteria and fungi (Table 3), as was found by Young et al. (2008). Removing soil from contaminated footwear is an effective first step in removing many organisms. It may be that for general situations, scrubbing footwear in fresh water will give a satisfactory level of bacteria and fungi control. Specific disinfectants can then be employed as needed in the event where passengers are arriving from disease outbreak regions (e.g. foot \& mouth disease) or for passengers known to have been in high risk environments (e.g. animal rearing facilities, farms or research facilities).

There was no visible colour change or apparent damage to footwear materials using the different disinfectants under a single treatment procedure. As most footwear is likely to be treated only once, the risk of long-term damage is minimal, although further testing with a measurable standard may need to be employed to quantify colour changes or test for unapparent damage to footwear fabrics.

Sodium hypochlorite and calcium hypochlorite, which are common household disinfectants, could be highly effective for footwear decontamination. Both of these disinfectants are cost effective and readily available in the market. However, the use of any disinfectant is subject to availability, cost and health and safety considerations, as well as other operational requirements at the border. 
In the present study the ability to control viruses has not been examined, and for this reason, further research is required to determine the efficacy of these disinfectants against viruses. In addition, the ability of these disinfectants to kill selected high-risk exotic bacteria (e.g. Xanthomonas fragariae Kennedy and King) and fungi (e.g. Phytophthora ramorum Werres and de Cock) should also be considered in future research.

\section{ACKNOWLEDGEMENTS}

This project was funded by the Foundation for Research, Science and Technology through the Better Border Biosecurity (B3) programme (www.b3nz.org). Disinfectants were supplied by Ecolab, Biocide Pacific Ltd and Postharvest Solutions Ltd. We thank Hospice Arohanui, Palmerston North Branch, for supply of used shoes. Ms SD Young advised on field test methods.

\section{REFERENCES}

Amass SF, Arighi M., Kinyon JM, Hoffman LJ, Schneider JL, Draper, DK 2006. Effectiveness of using a mat filled with peroxygen disinfectant to minimize shoe contamination in a veterinary hospital. Journal of the American Veterinary Medical Association 228 (9): 1391-1396.

Amass SF, Ragland D, Spicer P 2001. Evaluation of the efficacy of peroxygen compound, Virkon ${ }^{\circledR}$, as a boot bath disinfectant. Journal of Swine Health and Production 9: 121-123.

Amass SF, Schneider JL, Gaul AM 2005. Evaluation of current and novel protocols for disinfection of airplane passenger footwear under simulated conditions. Preventive Veterinary Medicine 71: 127-134.

Curry CH, McCarthy JS, Darragh HM, Wake RA, Churchill SE, Robins AM, Lowen RJ 2005. Identification of an agent suitable for disinfecting boots of visitors to the Antarctic. Polar Record 41 (216): 39-45.

Dunowska M, Morley PS, Patterson G, Hyatt DR, Van Metre DC 2006. Evaluation of the efficacy of a peroxygen disinfectant-filled footmat for reduction of bacterial load on footwear in a large animal hospital setting. Journal of the American Veterinary Medical Association 228: 1935-1939

Young SD, McNeill MR, Saville DJ 2008. Testing the effectiveness of disinfectant protocols for soiled footwear. New Zealand Plant Protection 61: 384 (Abstract only). 